\title{
Emotional Intelligence and Self-Efficacy: A Case of Iranian EFL University Students
}

\author{
Mohammad Reza Hashemi \\ Dep. of English Language and Literature, Ferdowsi University of Mashhad, Iran \\ E-mail: smrhir@gmail.com
}

Afsaneh Ghanizadeh (Corresponding author)

Dep. of English Language, Islamic Azad University, Mashhad Branch, Iran

Tel: 98-915-304-8141Ｅ-mail: ghanizadehafsaneh@yahoo.com

Received: August 15, 2011 Accepted: August 29, 2011 doi:10.5296/ijl.v3i1.877

\begin{abstract}
The present study aimed at investigating the relationship between EFL students' emotional intelligence and their sense of self-efficacy beliefs. The researchers of the present study set out to investigate this association based on theoretical contentions in the literature which demonstrated that self-efficacy is under the influence of several factors, one of which is the individual's emotional states. To empirically investigate the theorized relationship between self-efficacy and emotional intelligence, 97 EFL university students were selected according to convenience sampling from different universities in Iran. The participants were asked to complete the Bar-On EI test as well as the Learners' Self- Efficacy Survey. The findings of the study indicated that there is a significant relationship between EFL learners' emotional intelligence and their self-efficacy beliefs. Subsequent data analysis via regression revealed that among the components of emotional intelligence, self-actualization and stress tolerance are the positive predictors of the learners' self-efficacy. The results of the present study should encourage authorities and EFL teachers to incorporate skills and abilities associated with emotional intelligence in their curriculum and classroom activities. In so doing there is opportunity to enhance their self-efficacy, as well.
\end{abstract}

Key words: EFL university students, Emotional intelligence, Gender, Self-efficacy 


\section{Introduction}

Scholars in the field of educational psychology postulate that students' learning and their academic achievement are substantially influenced by the beliefs they hold about their capabilities to organize and successfully complete a task, i.e., the sense of self-efficacy beliefs (Bandura, 1997). A plethora of studies pointed to the facilitative role of self-efficacy beliefs in various academic and educational contexts (e.g. Pajares, 1996; Schunk \& Meece, 2005; Ghanizadeh \& Moafian, 2011a). In a similar vein, emotional skills have recently received considerable research interest in the field of education and psychology. Previous research demonstrated that emotional intelligence is associated with success in many areas, including effective teaching (Ghanizadeh \& Moafian, 2010), student learning (Brackett \& Mayer, 2003), and academic performance (Gil-Olarte, Palomera, \& Brackett, 2006).

The major aim of the present study is to investigate the association between self-efficacy and emotional intelligence among EFL university students. The researchers of the present study set out to investigate such a relationship based on logical reasoning followed from the theoretical and empirical studies in the literature that indicated the positive influence of emotional intelligence on learners' academic achievement and attitudes. This led the researchers to presume that this feeling of success may enhance learners' beliefs in their capabilities. An examination of self-efficacy and emotional intelligence literature also inspired the researchers to postulate a link between these two facets. For instance, Bandura (1986, 1991), the father of self-efficacy theory, contended that self-efficacy beliefs regulate functioning via several processes, one of which is the learner's affective state.

\section{Review of the Literature on Emotional Intelligence}

The literature related to emotional intelligence reveals that there are a multitude of definitions for what constitutes emotional intelligence. Salovey and Mayer (1990) viewed emotional intelligence as a type of social intelligence that involves the ability to monitor one's own and others' emotions and to use the information to guide thinking and actions. From this perspective, emotional intelligence is an umbrella term encompassing a collection of interpersonal and intrapersonal skills. The ability to comprehend the feelings of others, create and retain interpersonal relationships and, most importantly, our sense of social responsibility comprises interpersonal skills; and the ability to recognize and realize one's own motivations and emotions composes intrapersonal skills (Salovey \& Mayer, 1990). To measure emotional intelligence from this perspective, a skill-based model conceptualizing emotional intelligence as a set of abilities irrespective of personality traits or preferred ways of behaving was proposed. The proponents of the ability models of emotional intelligence contended that measures of emotional intelligence should be performance tests constrained to a set of emotion-related skills. For instance, the Mayer-Salovey-Caruso Emotional Intelligence Test (Mayer, Salovey, \& Caruso, 2002) requires the respondents to view a series of faces and report the extent to which each of six emotions is present, solve emotional problems, and answer questions about emotional scenarios. The test assesses the four sub skills of emotional intelligence as follows: The ability to accurately perceive, appraise, and express emotion; the 
ability to access or generate feelings on demand when they can facilitate understanding of oneself and another person; the ability to understand emotions and the knowledge that derives from them, and the ability to regulate emotions to promote emotional and intellectual growth (Salovey \& Mayer, 1990).

Other definitions and models of emotional intelligence conceptualize it as a mixed set of perceived abilities, skills, and personality traits. For Goleman (1998), a pioneer in the field, emotional intelligence is "the capacity for recognizing our own feelings and those of others, for motivating ourselves, and for managing emotions well in ourselves and in our relationship" (p. 317). To assess emotional intelligence from this perspective, the mixed models utilized self-report measures incorporating an array of perceived abilities and traits. Bar-On (2000), the designer of the world's mostly-used mixed measure of emotional intelligence, viewed it as an integration of interconnected emotional and social competencies and skills determining how successfully we comprehend and convey ourselves, realize others and communicate with them, and deal with the daily necessities and problems. The emotional and social competencies and skills in this conceptualization include the five key constructs and each of these constructs consists of a number of closely associated components as follows: (1) Intrapersonal (Self-Regard, Emotional Self Awareness, Assertiveness, Independence and Self- Actualization), (2) Interpersonal (Empathy, Social Responsibility and Interpersonal Relationship), (3) Stress Management (Stress Tolerance and Impulse Control), (4) Adaptability (Reality Testing, Flexibility and Problem Solving), and (5) General Mood (Optimism and Happiness) (Bar-On, 2006).

Compatible with this model and as it was mentioned, to be emotionally and socially intelligent means to be efficiently aware of and express oneself, to understand and communicate well with others, and to effectively tackle daily problems, requirements and pressures. This is indeed the manifestation of one's intrapersonal capability to know about oneself, to realize one's potencies and weak spots and to convey one's emotions and thoughts non-destructively. On the interpersonal level, being emotionally and socially intelligent includes the ability to comprehend others' emotions, feelings and needs, and to create and keep favorable, constructive and reciprocally satisfying associations. Finally, being emotionally and socially intelligent means reasonably and flexibly dealing with the instant situation, solving problems and making decisions. In so doing, emotions should be directed in a manner that work in favor of an individual and not against him, and he is required to be adequately hopeful, upbeat and active (Bar-On, 2006).

Despite the controversy over a unified definition or model for emotional intelligence, there is a general consensus that emotional skills are associated with success in many areas of life. In educational settings, it is widely accepted that to create opportunities for effective learning, students not only need content area knowledge, but also abilities associated with social and emotional competencies. Empirical studies demonstrated that emotional intelligence is positively correlated to academic achievement and other cognitive, affective, and metacognitive factors conducive to learning. For instance, Gil-Olarte, Palomera, and Brackett 
(2006) found a positive correlation between students' emotional intelligence and their academic success and social competence. In a similar vein, Bracket and Katluka (2007) indicated that their emotional literacy program designed to develop emotion-related skills in students will also promote abstract reasoning and reflective learning. Furthermore, Mortiboys (2005) contended that creating emotionally enhancing learning environments will increase the likelihood of learners' satisfaction, motivation and collaboration. The major implication put forward by these studies has been the need to integrate emotional literacy into the educational curriculum. These programs are expected to help students manipulate their emotions appropriately, shift undesirable emotional states to more productive ones, and understand the link between emotions, thoughts, and actions.

Likewise, more recently, the tenets pertained to emotional intelligence in attaining academic objectives have gained attention in EFL and ESL related research. What has emerged from these studies is compatible with the aforementioned contention that emotional intelligence has a contributing role in individuals' academic, affective and cognitive achievements. For instance, Fahim and Pishghadam's (2007) study demonstrated a positive relationship between university students' academic achievement and several components of emotional intelligence (intrapersonal, stress management, and general mood competencies). Aghasafari (2006) found a significant correlation between overall emotional intelligence measure and language learning strategies. More recently, situating critical thinking within the framework of emotional intelligence, Ghanizadeh and Moafian (2011b) indicated that emotional intelligence has a facilitative role in enhancing EFL learners' critical thinking ability. It has been also found that emotional intelligence plays a positive role in teaching effectiveness (Ghanizadeh \& Moafian, 2010).

\section{Review of the Literature on Self-efficacy}

In Social Foundations of Thought and Action (1986), Bandura proposed a social cognitive theory that emphasizes the role of self-referent phenomena and adopts an agentic view of personality. According to this agentic sociocognitive perspective, the underlying features of personal agency include intentionality, forethought, self-reactiveness, and self-reflectiveness. Bandura (2001) describes intention as "representation of a future course of action to be performed" (p. 6), that can originate actions for given purposes. The manifestation of forward looking plans, nevertheless, calls for more than an intentional state. What is needed is the exercise of forethought through which individuals are motivated and their actions are shaped in anticipation of future events. Successful implementation of intentions and plans, of course, entails not only the intentional ability to make choices and action plans, but also the ability to motivate and regulate the implementation of desired actions. According to Bandura (1986), this metacognitive ability is realized through self-regulatory processes that link thought to action and include self-monitoring, performance self-guidance via personal standards, and corrective self-reactions. The last distinctive core feature of Bandura's agentic sociocognitive theory pivots on individuals' capability of reflecting on themselves, their thoughts, and actions. For Bandura (1997), among the mentioned features, perceived self-efficacy, i.e., 
"beliefs in one's capabilities to organize and execute the courses of action required to produce given attainments" (p. 3), is the most fundamental and ubiquitous mechanism of personal agency. He also asserted how people behave can often be better predicted by the beliefs they hold about their own capabilities than by what they are actually capable of accomplishing.

Individual's beliefs about their efficacy can be developed by four main sources of influence. Bandura (1997) postulated theses sources of efficacy expectations as: mastery experience, also called enactive self-mastery, vicarious experience, also called role-modeling, social or verbal persuasion, and arousal or physiological and emotional states.

The most prevailing and powerful influence on efficacy is mastery experience through which successfully performing the behavior increases self-efficacy for that behavior. The perception that a performance has been successful enhances perceived self-efficacy and ensures future proficiency and success. The perception that a performance has been a failure weakens efficacy beliefs and leads to the expectation that future performance will also be inefficient. Self-mastery, according to Helsin (1997), is best achieved through breaking down complex task into its constituents that are easier to accomplish, in order to ensure a high level of initial success. Building self-efficacy via mastery experience or enactive mastery entails organizing situations that will offer individuals rewarding success and avoid their experiencing repeated failure.

The second prominent influence originates from observing other similar people to perform a behavior successfully. It provides people with ideas about successful manner. In contrast, observing people similar to oneself fail lowers the individual's confidence and subsequently undermines their efforts. An application of this source of efficacy in educational and career settings lies in the relative contribution of simulations for enhancing self-efficacy (Tompson \& Dass, 2002). In this regard, Wolfe (1997) maintained that "conscious and rational creation of a situation or environment within which the participants can learn by engaging in and reflecting on the activity or process being conducted" does demonstrate an improvement in self-efficacy (p. 443).

A third source of influence is social or verbal persuasion received from others. Successful persuaders foster people's beliefs in their capabilities, while at the same time, ensure that the visualized success is achievable. Negative persuasion, on the other hand, may tend to defeat and lower self-beliefs. The most contributing effect of social persuasion pivots around initiating the task, attempting new strategies, and trying hard to succeed (Pajares, 2002). Here it is worth mentioning although affirmative feedbacks enhance self-efficacy, attempts at constructing self efficacy through mere verbal persuasion may simply collapse into vacant sermons unless they are supported by efficacy-affirming experiences such as mastery experiences (Bandura, 1997).

Psychological and affective states, such as stress, anxiety, and excitement also provide information about efficacy perception and boost the feeling of proficiency. Hence, trying to reduce individual's stress and anxiety and to modify negative debilitative states to positive 
facilitator states plays an influential role in amending perceived self-efficacy beliefs. Another important affective factor, according to Pintrich and Schunk (2001), is attribution. If success is attributed to internal or controllable causes such as ability or effort, efficacy will be enhanced. Nevertheless, if success is attributed to external uncontrollable factors such as chance, self efficacy may be diminished (cited in Woolfolk Hoy \& Spero, 2000).

The tenets pertained to sense of efficacy in explaining behavior have received support from research in a variety of contexts and disciplines, including vocational behavior (Betz \& Hackett, 1981; Holland, 1997; Lindley \& Borgen, 2002), sport and exercise behavior (Short \& Sullivan, 2000; Toshima, Kaplan \& Ries, 1990), environmental behavior (Meinhold \& Malkus, 2005); and musical and vocal behavior (Neielsen, 2004).

Besides the aforementioned areas, arrays of studies have demonstrated the role of self-efficacy beliefs in various academic and educational contexts. Academic self-efficacy may be operationalized as "one's confidence in his ability to successfully perform pro-academic self-regulatory behaviors- the degree to which students metacognitively, motivationally, and behaviorally regulate their learning process" (Gore, 2006, p. 92). A substantial body of literature supports the relationship between students' self-efficacy beliefs for academic tasks and objectives and their academic performance on such diverse academic behaviors as, mathematics-specific self-efficacy (Lent, Brown, \& Gore, 1977; Pajares \& Miller, 1994), computer training (Gist, Schwoerer, \& Rosen, 1989), exam performance (Vrugt, Langereis, \& Hoogstraten, 1997; Yeperen, 2006), essay writing (Pajares \& Johnson, 1996), and language learning (Wong, 2005).

What has emerged from virtually all these studies is in line with Bandura's (1982) argument that those students with a higher degree of self-efficacy tend to exert more effort, persevere in difficult situations, choose course of activities more attentively, and retain more realistic and flexible attributions. While students low in self-efficacy display less persistence and effort expenditure, avoid uncertain and challenging tasks, lack intentionality, and possess attributions that are nonrealistic and maladaptive.

\section{Purpose of the Study}

As indicated earlier, abilities associated with emotional competencies have increasingly gained attention in research related to effectiveness and achievement in EFL contexts (Aghasafari, 2006; Fahim \& Pishghadam, 2007; Ghanizadeh \& Moafian, 2010). Reconsidering the sources of efficacy expectations, one may plausibly conclude that this sense of language learning success, as a manifestation of mastery experience, may tend to promote self-efficacy for L2 learning. So, it is plausible to assume that there may be a relationship between L2 learners' emotional intelligence and efficacy beliefs. The main purpose of the present study is to investigate the relationship between these two constructs among EFL university students. The secondary aim of the study is to delve into EFL learners' self-efficacy and emotional intelligence by examining the association of each these constructs with the learners' gender. 
To this end, the following questions were posed and investigated in this study:

1) Is there any significant relationship between EFL learners' self-efficacy and emotional intelligence?

2) Among the components of emotional intelligence which one(s) is/are the positive predictor(s) of their self-efficacy?

3) What percent of variability in learners' self-efficacy can be accounted for by taking their emotional intelligence into account?

4) Is there any significance difference between females and males regarding their emotional intelligence?

5) Is there any significance difference between females and males regarding their self-efficacy?

\section{Method}

\subsection{Participants}

The participants of the present study comprised 98 Iranian EFL university students. There were 57 females and 24 males; 17 participants did not specify their gender. Their age varied from 21 to 34 years old $(M=22, S D=2.15)$. They were seniors and juniors who were studying English Literature, Teaching and Translation at different universities across Iran.

\subsection{Instruments}

\subsubsection{EQ Test}

To evaluate students' emotional intelligence, the researchers employed Bar-On EI test which was designed by Bar-On in 1980. Bar-On EI test, called the emotional quotient inventory (EQ-I), is a self report measure of emotionally and socially intelligent behavior that provides an estimate of emotional-social intelligence (Bar-On, 1997). The test includes 133 items in the form of short sentences which measures five broad areas of skills and fifteen factorial components (discussed in Bar-On's model). It employs a five-point response scale with a textual response format ranging from 'very seldom' or 'not true of me' to 'very often' or 'true of me'. Each item has the value of 5 ranging to 1 . In the present study, a Persian version of EQ test was applied. According to Dehshiri (2003), this test and its subscales do have reliability and validity in Iranian culture. With the adapted version in Iran, the Cornbach's alpha coefficient was found to be 0.76 and the results of the factor analysis provided some support for the inventory hypothesized structure (Dehshiri, 2003). In this study, the total reliability of the questionnaire, estimated via Cronbach's alpha, was 0.80 .

\subsubsection{Learners' Self- Efficacy Survey}

To assess the EFL learners' level of self-efficacy, Learners' Self- Efficacy Survey designed and standardized by Gahungu (2009) was employed. The questionnaire operationalizes the self-efficacy construct via scores obtained on 40 items ranging from never to always (Gahungu, 2009). To estimate the reliability, the Kurder-Richardson 21 reliability was 
computed which was 0.97 . In the present study, the total reliability of the questionnaire was calculated via Cronbach's alpha which was found to be 0.91 .

\subsection{Data Collection}

The study was conducted in several universities in Iran, The participants were asked to take the Learners' Sense of Efficacy Survey and the Bar-On EI test. They took the questionnaires home, filled them in and during the following weeks submitted them to the researchers or their friends who were in charge of data collection. To receive the reliable data, the goal of filling out the questionnaires was explained to the subjects and they were assured that endevor would be made to observe the confidentiality and anonymity considerations. Besides, the participants' questionnaires were coded numerically and they were asked not to write a name on their questionnaires.

\section{Results}

Table 1 summarizes the descriptive results of the two instruments- Learners' Sense of Efficacy Survey (LSES) and the Bar-On EI (EQ) test- utilized in this study.

Table 1. Descriptive statistics of LSES \& EQ

\begin{tabular}{|c|c|c|c|c|c|}
\hline & $\mathbf{N}$ & Minimum & Maximum & Mean & Std. Deviation \\
\hline LSES & 98 & 50.00 & 156.00 & 103.74 & 24.12 \\
\hline EQ & 98 & 338.00 & 158.00 & 471.16 & 52.69 \\
\hline
\end{tabular}

To investigate the relationship between learners' self-efficacy and their emotional intelligence, a Pearson product-moment correlation was applied. The results of correlation revealed that there is a significant correlation between EFL learners' self-efficacy and their emotional intelligence $\left(\mathrm{r}=0.35^{*}, \mathrm{p}<0.05\right)$.

The results of multiple correlations indicated that among the components of EQ test, twelve of them have positive significant correlation with self-efficacy as follows: Emotional self-awareness $\left(\mathrm{r}=0.239^{*}, \mathrm{p}<0.05\right)$, Assertiveness $\left(\mathrm{r}=0.253^{*}, \mathrm{p}<0.05\right)$, Self-actualization $\left(\mathrm{r}=0.333^{*}, \mathrm{p}<0.05\right)$, Independence $\left(\mathrm{r}=0.265^{*}, \mathrm{p}<0.05\right)$, Empathy $\left(\mathrm{r}=0.287^{*}, \mathrm{p}<0.05\right)$, Social responsibility $\left(\mathrm{r}=0.222^{*}, \mathrm{p}<0.05\right)$, Interpersonal relationship $\left(\mathrm{r}=0.224^{*}, \mathrm{p}<0.05\right)$, Problem solving $\left(\mathrm{r}=0.224^{*}, \mathrm{p}<0.05\right)$, Reality testing $\left(\mathrm{r}=0.286^{*}, \mathrm{p}<0.05\right)$, Flexibility $(\mathrm{r}=$ 0.287*, $\mathrm{p}<0.05)$, Stress tolerance $\left(\mathrm{r}=0.396^{*}, \mathrm{p}<0.05\right)$, Impulse control $\left(\mathrm{r}=0.226^{*}, \mathrm{p}<\right.$ $0.05)$, Optimism $\left(\mathrm{r}=0.251^{*}, \mathrm{p}<0.05\right)$. As it can be seen, stress tolerance has the highest correlation with self-efficacy.

To investigate which factors of EQ might have more predictive power in predicting learners' self-efficacy and how other constructs contribute to this model, a regression analysis was employed. The following table is the ANOVA table of regression. The magnitude of F-value and the amount of the respective $\mathrm{p}$-value $(\mathrm{p}<0.05)$ indicate the considered model is significant (See Table 2). 
Table 2. The ANOVA table of regression

\begin{tabular}{|c|c|c|c|c|c|c|}
\hline \multicolumn{2}{|c|}{ Model } & $\begin{array}{c}\text { Sum of } \\
\text { Squares }\end{array}$ & df & Mean Square & F & Sig. \\
\hline \multirow{2}{*}{1} & Regression & 20865.008 & 17 & 1227.353 & 2.758 & $.001^{\mathrm{a}}$ \\
\cline { 2 - 8 } & Residual & 35601.614 & 80 & 445.020 & & \\
\cline { 2 - 8 } & Total & 56466.622 & 97 & & & \\
\hline
\end{tabular}

a. Predictors: (Constant), empathy, interpersonal, independence, problem solving, emotional awareness, flexibility, impulse control, happiness, stress tolerance, assertive, self-actualization, reality testing, optimism, social responsibility, self-regard

b. Dependent Variable: Self-efficacy

Table 3. The results of regression analysis for learners' EQ and Self-Efficacy

\begin{tabular}{|c|c|c|c|c|c|c|}
\hline & \multirow[t]{2}{*}{ Model } & \multicolumn{2}{|c|}{ Unstandardized Coefficients } & \multirow{2}{*}{$\begin{array}{c}\text { Standardized } \\
\text { Coefficients } \\
\text { Beta }\end{array}$} & \multirow[t]{2}{*}{$\mathrm{t}$} & \multirow[t]{2}{*}{ Sig. } \\
\hline & & B & Std. Error & & & \\
\hline \multirow[t]{16}{*}{1} & (Constant) & -8.753 & 27.124 & & -0.323 & 0.748 \\
\hline & $\begin{array}{c}\text { Emotional } \\
\text { self-awareness }\end{array}$ & 0.215 & 0.683 & 0.043 & 0.315 & 0.754 \\
\hline & Assertiveness & 1.292 & 0.831 & 0.217 & 1.555 & 0.124 \\
\hline & Self-regard & -1.165 & 0.775 & -0.276 & -1.502 & 0.137 \\
\hline & Self-actualization & 1.924 & 0.683 & 0.407 & 2.817 & 0.006 \\
\hline & Independence & 0.573 & 0.673 & 0.101 & 0.851 & 0.398 \\
\hline & Empathy & 1.012 & 1.008 & 0.175 & 1.004 & 0.318 \\
\hline & Interpersonal & -0.643 & 0.707 & -0.158 & -0.910 & 0.366 \\
\hline & $\begin{array}{c}\text { Social } \\
\text { responsibility }\end{array}$ & 0.703 & 0.854 & 0.138 & 0.823 & 0.413 \\
\hline & Problem solving & -0.340 & 0.569 & -.076 & -0.597 & 0.553 \\
\hline & Reality testing & 0.878 & 0.701 & 0.189 & 1.252 & 0.214 \\
\hline & Flexibility & 0.118 & 0.618 & 0.025 & 0.190 & 0.849 \\
\hline & Stress tolerance & 1.837 & 0.666 & 0.417 & 2.758 & 0.007 \\
\hline & Impulse control & 0.389 & 0.427 & 0.120 & 0.913 & 0.364 \\
\hline & Happiness & -1.298 & 0.652 & -0.306 & -1.990 & 0.059 \\
\hline & Optimism & -0.918 & 0.855 & -0.184 & -1.074 & 0.286 \\
\hline
\end{tabular}


As Table 3 displays, among the subscales of EQ, stress tolerance and self-actualization were found to be the positive predictors of the dependent variable (self-efficacy).

Table 4. R square table for EQ components as the predictors of Self-Efficacy

\begin{tabular}{|c|c|c|c|c|}
\hline Model & $\mathbf{R}$ & R Square & $\begin{array}{c}\text { Adjusted R } \\
\text { Square }\end{array}$ & Std. Error of the Estimate \\
\hline 1 & $0.608^{\text {a }}$ & 0.370 & 0.236 & 21.09550 \\
\hline $\begin{array}{l}\text { a. Predictors: (Constant),empathy, independence, problem solving, emotional } \\
\text { awareness, flexibility, impulse control, happiness, stress tolerance, assertive, self- } \\
\text { actualization, reality testing, optimism, social-responsibility, interpersonal } \\
\text { relationship, self-regard }\end{array}$
\end{tabular}

Table 4 illustrates the model summary statistics. The results revealed that the model containing all constructs of EQ can predict 24 percent of the learners' self-efficacy beliefs. In other words, it indicates that about $24 \%$ of the variation in learners' self-efficacy can be explained by taking the components of EQ into account.

Table 5. The results of independent t-tests for determining the role of gender in EQ \& Efficacy

\begin{tabular}{|c|c|c|c|c|c|}
\hline \multirow{2}{*}{} & \multicolumn{5}{|c|}{ T-test for Equality of Means } \\
\cline { 2 - 6 } & $\mathbf{t}$ & $\mathbf{d f}$ & Sig. (2-tailed) & $\begin{array}{c}\text { Mean } \\
\text { Difference }\end{array}$ & Std. Error Difference \\
\hline EQ & 0.200 & 81 & 0.842 & 2.538 & 12.689 \\
\hline Self-efficacy & 1.016 & 81 & 0.313 & 6.033 & 5.937 \\
\hline
\end{tabular}

To find out whether learners' efficacy and EQ differ among males and females, independent t-tests were run. As Table 5 displays gender plays any significant role in neither learners' EQ nor efficacy.

\section{Discussion}

The present study sought to investigate the possible association between EFL university students' emotional intelligence and their sense of self-efficacy beliefs. The results demonstrated that there is a positive association between the two constructs. In other words, EFL learners' emotional intelligence tends to enhance their beliefs in their capabilities to organize and execute the courses of action required for successful performance. This is in accordance with theoretical contentions in self-efficacy literature designating that self-efficacy is under the influence of four factors, one of which is the individual's affective and emotional states. The findings of the present study also confirmed previous empirical studies. For example, Chan (2007) indicated that individuals who exhibited high emotional intelligence had high self-efficacy. In a similar vein, Villanueva and Sánchez (2007) found that emotional intelligence was positively associated with leadership self-efficacy. Identical 
results have been reported in L2 context. Moafian and Ghanizadeh's (2009) study demonstrated that enhancing EFL teachers' emotional intelligence had a positive influence on their sense of efficacy beliefs and that teacher self-efficacy beliefs were significantly predicted by interpersonal-relationship and problem solving components of emotional intelligence.

The researchers' second question aimed at finding which component of EFL learners' emotional intelligence has the highest correlation with their self-efficacy and which ones are the positive predictors of self-efficacy. The results revealed that stress tolerance has the highest correlation and stress tolerance and self-actualization are the positive predictors of self-efficacy beliefs. The relationship between stress tolerance (the ability to cope with and manage stressful situations) and self-efficacy suggests that individuals who can manipulate debilitative emotional states hold stronger beliefs about their capabilities. This attests to Bandura's (1997) contention that facing challenges, individuals with low-self efficacy may see the situation more demanding than it is. This in turn may result in higher degrees of anxiety and stress and may make individuals demotivated. This finding also corroborates empirical studies demonstrating a negative association between self-perceptions and anxiety (MackIntyre \& Gardner, 1955; Kitano, 2001).

The relationship between self-efficacy and self-actualization (the ability to realize one's potential capacities) indicates that individuals who attempt to figure out their capabilities and who have more awareness of their true potentials are expected to have higher confidence in their abilities to perform required actions. This is hardly surprising since both of these factors, as their names suggest, are intrinsically derived with a focus on competence that underlies the self. Viewing from commonsense perspective, it is reasonable to presume an attempted awareness of perceived competence better equips individuals to form sound and realistic judgments of their capabilities to succeed in a particular situation.

The results of the third research question demonstrated that about 24 per cent of the variation in learners' self-efficacy can be explained by taking EI into account. This seems plausible since as indicated earlier individual's beliefs about their efficacy can be developed by four main sources including mastery experience, vicarious experience, social or verbal persuasion, and emotional states. According to Bandura (1997), although learners obtain information to judge their self-efficacy from all of these four sources, students' own performances on past tasks and vicarious experience appear to be the most influential guides. So it can be concluded attempts to enhance learners' beliefs in their capabilities should take into account other prominent factors involved in the development self-efficacy perceptions.

The researcher's fourth question investigated the relationship between EFL university learners' emotional intelligence and gender. The results indicated that there was no difference between males and females in the magnitude of their emotional intelligence. This is in contrast with the widely held view that females are emotionally more intelligent than males. Previous studies have almost conclusively indicated that individuals' emotional intelligence changes with the gender differences. For instance, Perry, Ball and Stacey (2004) and Day and 
Carroll (2004) pointed out that females reported higher EI than did male.

The fifth research question examined whether there is any significance difference between female and male students regarding their sense of self-efficacy beliefs. The results indicated that there was no relationship between the two variables in question. The issue of gender differences in self-efficacy has remained an area of controversy among researchers. Tschannen-Moran and Woolfolk Hoy's (2002) study revealed that gender differences do not significantly predict individual's self-efficacy beliefs. In a similar vein, Pajares (2002) postulated that males and females do not differ significantly in their sense of self-efficacy beliefs. In contrast, Coladarci (1992) as well as Ross (1994) found statistical difference between females and males' self-efficacy with the females having higher self-efficacy indices than their male counterparts.

The major conclusion derived from the present study demonstrates that enhancing EFL students' emotional intelligence tends to promote their sense of self-efficacy beliefs. As indicated earlier, a substantial body of literature supports the facilitative role of self-efficacy beliefs in academic performance, attitudes, and motivation (e.g., Bandura, 1997; Pajeres, 2002; Wong, 2005; Ghanizadeh \& Moafian, 2011 a). So this in turn should encourage authorities and EFL teachers to incorporate skills and abilities associated with emotional intelligence in their curriculum and classroom activities. These programs and activities should be targeted at both male and female students and highlight the contributing impact of stress tolerance and self-actualization on the enhancement of self-efficacy perceptions.

The results of the present study lead to several recommendations for further research. Future studies utilizing qualitative approaches such as interviews, case studies, and observations could explore the processes by which self-efficacy and emotional intelligence nurture in the classroom context. Further research should also investigate the impact of factors such as social and family background, age, and academic achievement on the development of these two constructs.

\section{References}

Aghasafari, M. (2006). On the relationship between emotional intelligence and language learning strategies. MA Thesis, Allameh Tabataba'ii University, Tehran.

Bandura, A. (1982). Self -efficacy mechanism in human agency. American Psychologist, 37, 122-147. http://dx.doi.org/10.1037/0003-066X.37.2.122

Bandura, A. (1986). Social foundations of thought and action: A social cognitive theory. Englewood Cliffs, NJ: Prentice-Hall.

Bandura, A. (1997). Self-efficacy: the exercise of control. New York, NY: Freeman.

Bandura, A. (2001). Social cognitive theory: An agentic perspective. Annual Review Psychology, 52, 1-26. http://dx.doi.org/10.1146/annurev.psych.52.1.1

Bar-On, R. (1997). The emotional quotient inventory (EQ-I): Technical manual. Toronto: 
Multi-Health Systems.

Bar-On, R. (2000). Emotional and social intelligence. Insights from the emotional quotient inventory (EQ-I). In: Bar-On, R., Parker, J.D. (Eds.), The Handbook of Emotional Intelligence (pp. 363-388). Jossey-Bass, San Francisco.

Bar-On, R. (2006). The Bar-On model of emotional-social intelligence (ESI). Psicothema, 18 (Suppl), 13-25.

Betz, N. E., \& Hackett, G. (1981). The relationship of career-related self-efficacy expectations to perceived career optoins in college women and men. Journal of Counseling Psychology, 28, 399-410. http://dx.doi.org/10.1037/0022-0167.28.5.399

Brackett, M.A., \& Katulak, N. (2007). The emotionally intelligent classroom: Skill-based training for teachers and students. In J. Ciarrochi \& J. D. Mayer (Eds.), Improving emotional intelligence: A practitioner's guide. New York: Psychology Press/Taylor \& Francis.

Brackett, M. A., \& Mayer. J. D. (2003). Convergent, discriminant, and incremental validity of competing measures of emotional intelligence. Personality and Social Psychology Bulletin, 29(9), 1147-58.

Chan, D. W. (2007). Emotional intelligence, self-efficacy, and coping among Chinese prospective and in-service teachers in Hong Kong. Educational Psychology, 28(4), 397-408. http://dx.doi.org/10.1080/01443410701668372

Coladarci, T. (1992). Teachers' sense of efficacy and commitment to teaching. Journal of Experimental Education, 60, 323-337. http://dx.doi.org/10.1080/00220973.1992.9943869

Day, A. L., \& Carroll. S. A. (2004). Using an ability-based measure of emotional intelligence to predict individual performance, group performance, and group citizenship behaviours. Personality and Individual Differences, $36 \quad$ (6), 1443-1458. http://dx.doi.org/10.1016/S0191-8869(03)00240-X

Dehshiri, R. (2003). The reliability and validity of EQ-I in Iranian context. Unpublished master's thesis, Allame Tabatabaee University, Tehran, Iran.

Fahim, M., \& Pishghadam, R. (2007). On the role of emotional, psychometric, and verbal intelligences in the academic achievement of university students majoring in English Language. Asian EFL Journal, 9(4), 240-253.

Gahungu, O. (2009). Strategy use, self-efficacy, and language ability: Their relationship. Germany: Lambert Academic Publishing.

Ghanizadeh, A., \& Moafian, F. (2010). The role of EFL teachers' emotional intelligence in their success. ELT Journal, 64 (4), 424-435. http://dx.doi.org/10.1093/elt/ccp084

Ghanizadeh, A., \& Moafian, F. (2011a). The relationship between Iranian EFL teachers' sense of self-efficacy and their pedagogical success in Language Institutes. Asian EFL Journal, 
13(2), 249-272.

Ghanizadeh, A., \& Moafian, M. (2011b). Critical thinking and emotional intelligence: investigating possible relationships among EFL learners and the contribution of age and gender. Iranian Journal of Applied Linguistics, 14 (1), 25-50.

Gil-Olarte, P., Palomera, R., \& Brackett, M.A., (2006). Relating emotional intelligence to social competence and academic achievement in high school students. Psicothema, 18 (Suppl.), 118-123.

Gist, M. E., Schwoerer, C., \& Rosen, B. (1989). Effects of alternative training methods on self-efficacy and performance in computer software training. Journal of Applied Psychology, 74, 884-891. http://dx.doi.org/10.1037/0021-9010.74.6.884

Goleman, D. (1998). Working with emotional intelligence. New York: Bantam Books.

Helsin, P. A. (1999). Boosting empowerment by developing self-efficacy. Asia Pacific Journal of Human Resources, 37(1), 52-64. [Online] Available: http://apj.sagepub.com/cgi/content/37/1/52 (November 27).

Holland, J.L. (1997). Making vocational choices: A theory of vocational personalities and work environments (3rd ed) Odessa, FL: Psychological Assessment Resources.

Kitano, K. (2001). Anxiety in the college Japanese language classroom. Modern Language Journal, 85 (4), 549-566.

Lent, R. W., Brown, S. D., \& Larkin, K. C. (1987). Comparison of three theoretically derived variables in predicting career and academic behavior: Self-efficacy, interest congruence, and consequence thinking. Journal of Counseling Psychology, 34, 293-298. http://dx.doi.org/10.1037/0022-0167.34.3.293

Lindley, L. D., \& Borgen, F. H. (2002). Generalized self-efficacy, Holland theme self-efficacy, and academic performance. Journal of career assessment, 10, 301-334. http://dx.doi.org/10.1177/10672702010003002

MacIntyre, P., \& Gardner, R.C. (1991). Language Anxiety. Language Learning, 41(2), 513-534. http://dx.doi.org/10.1111/j.1467-1770.1991.tb00691.x

Mayer, J. D., Salovey, P., \& Caruso, D.R. (2002). Mayer-Salovey-Caruso Emotional Intelligence Test (MSCEIT) user's manual. Toronto, Canada: MHS Publishers.

Meinhold, J. A., \& Malkus, A. J. (2005). Adolescent environmental behaviors: can knowledge, attitudes, and self-Efficacy make a difference? Environment and Behavior, 37, 511-532. http://dx.doi.org/10.1177/0013916504269665

Moafian, F., \& Ghanizadeh, A. (2009). The relationship between Iranian EFL teachers' emotional intelligence and their self-efficacy in Language Institutes. System, 37(4), 708-718.

Mortiboys, A. (2005). Teaching with Emotional Intelligence: A Step-by-Step Guide for Higher 
and Further Education Professionals. London: Routledge.

Nielson, S. G. (2004). Strategies and self-efficacy beliefs in instrumental and vocal individual practice: a study of students in higher music education. Society for Education, Music and Psychology Research, 32 (4), 418-431. http://dx.doi.org/10.1177/0305735604046099

Pajares, F. (1996). Self-efficacy beliefs in academic settings. Review of Educational Research, 66 (4), 543-578. http://dx.doi.org/10.2307/1170653

Pajares, F. (2002). Gender and perceived self-efficacy in self regulated learning. Theory into Practice, 41(2). http://dx.doi.org/10.1207/s15430421tip4102_8

Pajares, F., \& Johnson, M. J. (1996). Self-efficacy beliefs in the writing of high school students: A path analysis. Psychology in the Schools, 33, 163-175. http://dx.doi.org/10.1002/(SICI)1520-6807(199604)33:2<163::AID-PITS10>3.0.CO;2-C

Pajares, F., \& Miller, M.D. (1995). Mathematics self-efficacy and mathematics performances: The need for specificity of assessment. Journal of Counseling Psychology, 42, 190-198. http://dx.doi.org/10.1037/0022-0167.42.2.190

Perry, C., Ball, I., \& Stacey, E., (2004). Emotional intelligence and teaching situations: Development of a new measure. Issues in Educational Research, 14(1), 29-43.

Pintrich, P. R., \& Schunk, D. H. (2001). Motivation in education: Theory, research, and applications (2nd ed.). Englewood Cliffs, NJ: Merrill/Prentice-Hall.

Ross, J. A. (1994). The impact of an inservice program to promote cooperative learning on the stability of teacher efficacy. Teaching \& Teacher Education, 10 (4), 381-394. http://dx.doi.org/10.1016/0742-051X(94)90020-5

Salovey, P., \& J.D. Mayer. (1990). Emotional intelligence. Imagination, cognition, and Personality, 9, 185-211.

Schunk, D. H., \& Meece, J. L. (2005). Self-efficacy beliefs of adolescents. Information Age Publishing

Tompson, G. H., \& Dass, P. (2000). Improving students' self-efficacy in strategic management: the relative impact of cases and simulations. Simulation Gaming, 31 (1), 22-41. [Online] Available: http://apj.sagepub.com/cgi/content/31/1/22 (November10, 2007).

Toshima, M. T., Kaplan, R. M., \& Ries, A. L. (1990). Experimental evaluation of rehabilitation in chronic obstructive pulmonary disease: Short-term effects on exercise endurance and health status. Health Psychology, 9, 237-252. http://dx.doi.org/10.1037/0278-6133.9.3.237

Tschannen-Moran, M., \& Woolfolk Hoy, A. (2002, April). The influence of resources and support on teachers' efficacy beliefs. Paper presented at the annual meeting of the American Educational Research Association, San Diego, CA. [Online] Available: 


\section{Macrothink}

International Journal of Linguistics

ISSN 1948-5425

2011, Vol. 3, No. 1: E29

http://www.coe.ohio-state.edu/ahoy/AERA\%202002\%20megan.pdf. (May 12, 2009).

Villanueva, J.J., \& Sánchez, J.C. (2007). Trait emotional intelligence and leadership self-efficacy: Their relationship with collective efficacy. The Spanish Journal of Psychology, 10 (2), 349-357. PMid:17992961

Vrugt, A. J., Langereis, M. P. \& Hoogstraten, J. 1997). Academic self-efficacy and malleability of relevant capabilities as predictors of exam performance. Journal of Experimental Education, 66, 61-72. http://dx.doi.org/10.1080/00220979709601395

Wolfe, J. (1997). The effectiveness of business games in strategic management course work. Simulation \& Gaming: An International Journal, 28, 360-375.

Wong, M. S. L. (2005). Language learning strategies and language self-efficacy: investigating the relationship in Malaysia. ERLC Journal, 36, 245-271. [Online] Available: http://rel.sagepub.com/cgi/content/abstract/36/3/245 (November, 2007).

Woolfolk Hoy, A. W., \& Spero, R. B. (2000). Changes in teacher efficacy during the early years of teaching: an exploratory study. [Online] Available: http://des.emory.edu/mfp/efftalk.html (July, 2007)

Yeperen, N. W. V. (2006). A novel approach to assessing achievement goals in the context of the $2 \times 2$ framework: identifying distinct profiles of individuals with different dominant achievement goals. Personality and Social Psychology Bulletin, 32 (11), 1432-14445. [Online] Available: http://psp.sagepub.com/cgi/content/abstract/32/11/1432 (May, 2007). 